\title{
Occurrence of Gastrointestinal Helminths in rabbits with special Reference to Importance of Giardia spp. as Parasitic Zoonoses
}

\author{
Rewatkar SG $^{1^{*}}$, Deshmukh SS ${ }^{1}$, Prem Kumar $\mathbf{G}^{2}$, Maske, $\mathrm{DK}^{1}$ and Bhangale, $\mathrm{GN}^{1}$ \\ Department of Veterinary Parasitology, Nagpur Veterinary College, M. A. F. S. U., Seminary Hills, Nagpur- \\ 440006, Maharastra State, India \\ ${ }^{1}$ Department of Veterinary Pharmacology, Bangalore Veterinary College, K.V.A.F.S.U., Bangalore-560024, \\ Karnataka, India
}

\begin{tabular}{|c|c|}
\hline Abstract & Article Information \\
\hline \multirow{3}{*}{$\begin{array}{l}\text { The aim of this study was to detect Giardia spp. as zoonotic helminth as } \\
\text { Giardiosis has been recognised as the one of the important parasitic diarrhoea } \\
\text { among children as cross transmission may occur between human and rabbits. } \\
\text { Other helminths in rabbits may causes ill health and sometimes proved fatal. } \\
\text { Faecal samples of } 42 \text { rabbits of different age group (1-4 years) from Nagpur } \\
\text { and Akola regions, India were examined. The study was conducted during June } \\
\text { to August } 2008 \text {. Faecal sample examination revealed presence of mixed } \\
\text { infection of eggs of parasites like Giardia spp. (19.04\%), Trichostrongyle spp. } \\
\text { (28.57\%), Graphidium spp. (19.04\%), Coccidia spp. (16.66\%) and Passaluras }\end{array}$} & $\begin{array}{l}\text { Article History: } \\
\text { Received : } 11-08-2013 \\
\text { Revised : 25-09-2013 } \\
\text { Accepted : 28-09-2013 } \\
\end{array}$ \\
\hline & $\begin{array}{l}\text { Keywords: } \\
\text { Rabbit } \\
\text { Parasitic diarrhoea }\end{array}$ \\
\hline & $\begin{array}{l}\text { *Corresponding Author: } \\
\text { Rewatkar SG } \\
\text { E-mail: } \\
\text { rewatkarswap2006@gmail.com }\end{array}$ \\
\hline
\end{tabular}

\section{INTRODUCTION}

Rabbits are small mammals in the family Leporidae of the order Lagomorpha, found in several parts of the world. Rabbit habitats include meadows, woods, forests, grasslands, deserts and wetlands. Rabbits are herbivores that feed by grazing on grass, forbs, and leafy weeds. In consequence, their diet contains large amounts of cellulose, which is hard to digest. Rabbits solve this problem by passing two distinct types of feces: hard droppings and soft black viscous pellets, the latter of which are known as caecotrophs and are immediately eaten. Rabbits reingest their own droppings to digest their food further and extract sufficient nutrients (Oaktreevet, 2010).

Rabbits are generally infected with numerous parasites. Parasitic infections have caused considerable losses to rabbits in the region. Numbers of parasites are responsible for illness of rabbits (Allan et al., 1999). Helminthic infection have greater ramification and significant impact in these animals, when present in sufficient number can cause high morbidity and mortality. These may be expressed as deaths in all age groups especially in young ones and weakness and unthreftyness in survivor who may, as a result have lowered body resistance and reproduction capabilities.

In order to understand rate of helminthic infection in rabbits, a study was carried out in Nagpur and Akola region in pre monsoon and post monsoon season of the year. This paper attempts to provide some more information regarding parasitic infection along with parasitic zoonosis through rabbits.

\section{MATERIALS AND METHODS}

Total of 42 samples of rabbits were collected from Nagpur and Akola region, India. Freshly collected faecal samples were processed and examined grossly and microscopically for qualitative examination, adopting standard procedures. In brief, faecal samples were collected in sterilized glass bottles. They were processed by direct smear and Sedimentation techniques. A drop of sediment was examined under low power objective of light microscope. The identification of parasitic eggs was done by morphological characters as described by Soulsby (1982). 


\section{RESULT AND DISCUSSION}

Out of 42 samples examined $73 \%$ were positive for helminthic infection and many of them showed mixed infection (Table 1). Boag (1985) observed that incidence of helminth parasites from the wild rabbit Oryctolagus cuniculus (L.) in eastern Scotland. It showed that Trichostrongylus sp., Passalurus sp and Graphidium $s p$ infections were greatest in the infected animals.

Table 1: Incidence of helminth Parasites in Rabbits.

\begin{tabular}{clccc}
\hline $\begin{array}{c}\text { SI } \\
\text { No }\end{array}$ & \multicolumn{1}{c}{ Parasites } & $\begin{array}{c}\text { Total } \\
\text { Samples }\end{array}$ & $\begin{array}{c}\text { Positive } \\
\text { samples }\end{array}$ & $\begin{array}{c}\text { Incidence } \\
\text { Rate }\end{array}$ \\
\hline 1 & Giardia spp. & 42 & 8 & $19.04 \%$ \\
2 & Trichostrongyle spp. & 42 & 12 & $28.57 \%$ \\
3 & Graphidium spp. & 42 & 8 & $19.04 \%$ \\
4 & Coccidia spp. & 42 & 7 & $16.66 \%$ \\
5 & Passalurus spp. & 42 & 6 & $14.28 \%$ \\
\hline
\end{tabular}

Eight samples were found positive for Giardia spp. (19.04\%). The Giardia spp. has zoonotic importance. Giardiosis has been recognised as important parasitic diarrhoea in China in recent years. Trophozoits of Giardia spp. were also isolated from three human and a rabbit. This indicate that isolates from human and rabbits do not have strict host specificity and cross transmission may occur between human and rabbits (Lu et al., 1996). Foronda et al. (2003) studied the presence of mixed parasitic infection in wild rabbits in Macaronesia. Present study resemblance with the Foronda studies showing common parasite infection of Trichostrongyle spp., Passalurus spp., and Graphidium spp. Eira et al. (2007) reported infection of Graphidium spp., Passalurus spp., Trichostrongyle spp. in rabbit (Oryctolagus cuniculus) and their effect on host condition in Dunas de Mira, Portugal.

\section{CONCLUSION}

Parasitic infestation is commonly occurred in rabbit and is responsible for the reducing general and reproductive health in rabbits. Additionally zoonosis is also an emerging issue due to humanwild interactions and changing in food habitat. Despite the clear importance of understanding and controlling zoonotic diseases not had much success eradicating them, or even limiting their spread. So there is need to pre-emptively in identify such emerging diseases, via monitoring of wild animals to control zoonosis harmful effect.

\section{ACKNOWLEDGEMENT}

Authors are thankful to the Associate Dean, Nagpur Veterinary College, Nagpur for providing necessary facilities.

\section{REFERENCES}

Allan, J.C., Craig, P.S., Sherington, J., Rogan, M.T., Storey, D.M., Heath, S. and Iball, K. (1999). Helminth parasites of wild rabbit Oryctologus cuniculus Yorkshire, UK. Journal of Helminthology 73: 289-294.

Boag, B. (1985). The incidence of helminth parasites from the wild rabbit Oryctolagus cuniculus (L.) in eastern Scotland. Journal of Helminthology 59(1):61-69.

Eira C., Torres, J., Miquel, J and Vingad, J. (2007). The helminth parasites of the wild rabbit Oryctolagus cuniculus and their effect on host condition in Dunas de Mira, Portugal. Journal of Helminthology 81(3):23946.

Foronda, P., Valladares, B., Lorenzo-Morales, J., Ribas, A., Feliu, C. And Casanova, J., (2003). Helminths of the wild rabbit (Oryctolagus cuniculus) in Macaronesia. Jolurnal of Parasitology 89(5):952-957.

Lu, S.Q., Wang, Z.Y., Yan, G., Chen, P.H., Zhu, H., Gao, Z.Z. and Wang, F.Y. (1996). Four Isolates of Giardia lambia Cultivated Axenically in China and the Restriction Endonuclease of Their DNA. Journal of Parasitology 82(4): 659-661.

Molina, X., Casanova, J.C. and Feliu, C. (1999). Influence of host, weight, sex and reproductive status on helminth parasites of the wild rabbit Oryctologus cuniculus in Novora, Spain. Journal of Helminthology 73: $55-65$.

Soulsby, E.J.L. (1982). Helminths, Arthropods and Protozoa of Domesticated animals. $7^{\text {th }}$ edition ELBS and Baillere Tindall, London. 